\title{
The Internet Use and Addiction by University Adolescent Students
}

${ }^{1}$ Amal Ahmed Khalil; ${ }^{2}$ Amal Sobhy Mahmoud; ${ }^{3}$ Abeer Elsayed Berma; ${ }^{4}$ Huda Gaber Hamzaa

\author{
${ }^{1}$ Professor of Pediatric Nursing, ${ }^{2}$ Assistant Professor of Psychiatric Nursing and Mental \\ Health, ${ }^{3}$ Lecturer of Psychiatric Nursing and Mental Health, ${ }^{4}$ Assistant lecturer of \\ Psychiatric Nursing and Mental Health, Faculty of Nursing, Port Said University
}

\begin{abstract}
Background: Internet addiction is regarded as risk-taking behaviors among adolescents. Dysfunctional use of the internet may interfere with the person's social life, school work, and at certain occasions constituting a predisposing factor for the appearance of psychiatric disorders. Aim: This study was to assess internet use and addiction by university adolescent students. Subjects and Method: A descriptive research design was followed in this study. The subject of the study compromised 515 university students (311 were females and 204 were males), their age ranging from 18 to 19 years in all twelve faculties in Port Said governorate. The following tools were utilized to collect the necessary data for this study (Internet addictive behavior scale and personal data for the students and their parents) Results: The study revealed that, more than one-quarter of studied students was using the internet for 3hours and more per day. Severe/ extremely severe internet addiction levels were higher among female students and human sciences students. Conclusion and Recommendation: Most of the studied students were moderate of internet addictive behavior scale. Thus, the study recommended continuous educational programs for adolescents to teach them about the proper internet usage to avoid negative impacts on psychological status and replace the excessive use of the internet with health activity(such as sports). An educational session to parents about the supervisory role of the parents at home.
\end{abstract}

Keywords: Adolescents students, Internet addiction, and Internet use. 


\section{INTRODUCTION}

The internet is a new tool that is evolving into an essential part of everyday life all over the world and its use increases, especially among young people. In spite of the widely perceived merits of this tool, psychologists and educators have been aware of the negative impacts of its use, especially the over or misuse and the related physical and psychological problems. One of the most common of these problems is internet addiction (Akin \& Iskender, 2011).

Adolescents are young people between the ages of 10 and 19 years (WHO, 2014). Adolescence is a transitional period marked by significant changes in physical, cognitive and socio-emotional domains (Dreier et al., 2013). College student appears to be particularly prone to internet overuse. Several contributing factors to the special vulnerability of college students include free unlimited access to the internet, unstructured schedules, and new freedom from parental control, and desire to escape college and social stressors (Christopherson, 2008).

In China, Lam et al. (2009) found that $10.8 \%$ of adolescents were moderately to severely addict to the internet. Further, Ni et al. (2009) had also revealed that $6.44 \%$ of first-year university students were addicted to the internet. In Italy, Milani et al. (2009) found that $36.7 \%$ of adolescents had signs of problematic internet use.

In Egypt, the World Bank group (2014) indicated that Egypt now has the largest internet market in Africa which the prevalence rate of internet use in the year 2012 was $44.1 \%$. According to the internet usage statistics, internet users are increasing in Egypt. There were about 29 million users (35.6\% of the population) in 2012, compared to 12.8 million in 2008 (Desouky \& Ibrahem, 2015).

There is evidence that internet addiction has a negative effect on academics (a drop in grades), family relations (having to hide their excessive internet use from parents), physical health (sleep deprivation due to long hours of internet use), mental health (depression), and finance (cost of accrued internet expenses) (Chou et al., 2005). Moreover, Naffise et al. (2013) shown that internet addiction can cause sleep disorders, malnourishment, impaired interpersonal relationships, depression, anxiety and other psychiatric and somatic problems. For example, sleep disturbances and impairment of nutrition can cause growth retardation. Meanwhile, impairment in nutrition and low activity can cause obesity, osteoporosis and bone fractures leading to poor health.

The role of the psychiatric nurse is to contribute to the preventive and therapeutic intervention to face this phenomenon. So the psychiatric nurse should help students to understand the effects of excessive internet usage on themselves physically and mentally and how to overcome these impacts of internet addiction.

\section{Significance of the study:}

The university student population has been regarded as one of the most susceptible to developing internet addiction among all demographic groups of internet users. 
Dysfunctional use of such technology probably leads to changes in the psychological profiles of the young population and may interfere with the person's social life, school work, or job-related tasks at work, enhancing withdrawal from the real world, and at certain occasions constituting a predisposing factor for the appearance of psychiatric disorders.

\section{AIM OF STUDY:}

The aim of this study was to assess internet use and addiction by university adolescent students.

\section{SUBJECTS AND METHOD:}

\section{Research design}

A descriptive cross-sectional analytic research design was followed in this study.

\section{Study setting:}

The study was conducted in all twelve faculties in Port Said university; faculties were categorized into human sciences (science, commerce, physical education, kinder-garden, arts, education, and specific education), mathematical sciences (engineering and computer sciences), and healthy sciences (medicine, pharmacy, and nursing).

\section{Study subjects:}

The study subjects comprised any adolescents student from both sexes and aged between (16-19) years old enrolled in aforementioned faculties are eligible for inclusion in the study sample (The total sample size amounted to 515 students). The recruitment of students from each faculty was by convenience sampling.

\section{Sample size:}

To achieve the study objective, the sample size was determined by using the following equation. Since the prevalence of internet use in Egypt at 2012 was $44.1 \%$ as reported by the World Bank Group (2014) this substituting in the following equation:

$$
\mathrm{Z}(\mathrm{P} \mathrm{q})_{2}
$$

\section{Sample Size $(\mathbf{n})=$}

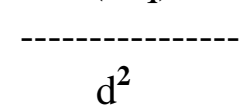
Where:
Z: 1.96
P: Prevalence of internet use
q: $(1-11.87)(1-P)$
d: Is width of the desired sample confidence interval $=0.098$.
$\mathbf{d}^{2}: 0.00960$
n: $=469$ adolescent

- Due to the expected drop-out rate (10\%) the studying sample size was 515 students.

- Number of students from each faculty has been determined according to the following equation :

Total number of students in the faculty $\mathrm{X}$ Total sample size

Total number of all faculties' students 


\section{Tools of data collection:}

\section{TOOL I: Sociodemographic Questionnaire:}

It consists of two parts:

PART 1: It was developed by the researcher. It includes all the related personal data for the students including age, gender, faculty name, residence.

PART 2: It consists of seven questions that cover internet use; it was developed by the researcher after reviewing the related literature (Morsy \& Shalaby, 2012; El kotb, 2013). This tool tested for their content validity by a jury of five experts in the psychiatric nursing, pediatric nursing and medicine fields to ascertain their validity and relevance. The required modifications were carried out accordingly.

\section{TOOL II: Internet addictive behavior scale (Modified Version):}

This scale was developed by Wadie (2006). It is an Egyptian Arabic inventory. It was modified and adopted by $\boldsymbol{E l}$ kotb (2013). It consists of 106 items. Student responses were in four Likert scales from 1 (never) to 4 (always). It measures the following aspects: Assessment of habitual internet usage (14 items), purpose of internet usage (12 items), effects of internet usage on physical health (17 items), effects of internet usage on psychosocial status (31 items), effects of internet usage on financial state (4 items), dependence, tolerance, and withdrawal symptoms (21 items) and effects of internet on academic achievement (7 items).

\section{Pilot Study:}

A pilot study was carried out on $10 \%$ (52 students) of the study subjects to test the tools before starting the data collection. The purposes of the pilot study were to test the clarity applicability and the feasibility of the study tools and to estimate the time needed to fill in the tools. It also helped to find out any obstacles and problems that might interfere with data collection. According to the pilot study, certain modifications were done, and hence the pilot students were excluded from the main study sample.

\section{Method of Data Collection:}

- From each faculty, an identified number of students were included in the study.

- Any student enrolled in the first grade of afore a mentioned faculty was eligible for inclusion in the study sample. The recruitment of students was by convenience sampling.

- In each faculty, the researcher attended the faculty dean's office to introduce self, explain the purpose of the study and the sampling technique that will be followed; then, the dean referred the researcher to the responsible lecturer of each academic year "coordinator".

- Students' oral consents were taken, and they were informed about their rights to refuse participation in the study. The researcher arranged with the coordinator for the most suitable day for data collection, in which all students would be in the faculty. In the determined day, the researcher with the coordinator attended the class in which the students were present; then, the researcher introduced herself and aim of the study. Students were then grouped into a class. Then, the researcher distributed the tools, accompanied that with an explanation of the purpose and use of each tool. Each interview lasted for 35-45 minutes, depending on the response of the interviewee. 
- The researcher started to collect data three times per week, and the process of data collection lasted for a period of four months from $20^{\text {th }}$ February to $20^{\text {th }}$ June 2014.

\section{ADMINISTRATIVE DESIGN:}

Before starting any step in the study, official letters were issued from the dean of the faculty of nursing to deans of all faculties in Port-Said city requesting their cooperation and permission to conduct the study, after explaining the aim of the study.

\section{Ethical Considerations:}

The research proposal was approved by the pertinent committees in the Faculty of Nursing. The researcher explained the aim of the study to Deans of all Faculties in PortSaid governorate to take their permission to carry out the study. Before starting the interview a verbal consent was taken from the students and after a short introduction about the aim of the study in order to gain student's cooperation. The researcher also informed them about their rights to refuse. They were ensured that any information obtained will be confidential and used only for the purpose of the study. Also, they were told that there were no right or wrong answers; it is a just honest expression of their feelings and behaviors, "privacy".

\section{Statistical Design:}

\section{Scoring System:}

Concerning Internet Addictive Behavior Scale Raw scores for each item range from 1-4; never (1), rarely (2), usually (3), and always (4). As suggested by Sally (2006), cut-off scores for the internet addictive behavior scale were used to classify internet users based on the severity of their addictive behavior (Sally, 2006).

In current study, the same cut-off scores were used:

* Minimal users (scores $<40 \%$ ): average online users who have complete control over their internet usage.

* Moderate users (scores 40-<70\%): those experiencing occasional or frequent problems due to internet usage.

* Excessive users (scores $70-\leq 100 \%$ ): those having significant problems caused by internet usage.

\section{Statistical Analysis:}

Data were entered into the SPSS software program (version 18.0). Findings were presented in tables. Both descriptive and inferential statistics were used such as mean, percentage, standard deviation, Chi-Squire, and Spearman Rho correlation coefficient. The statistically significant difference was considered when P-Value $\leq 0.05$.

\section{RESULTS:}

Table (1): illustrates that more than half of the studied students (60.4\%) were female, while the rest of them $(39.6 \%)$ were males. Looking at their residence, the majority of the studied students $(86.4 \%)$ were living in urban. Around two third of studied student $(65.8 \%)$ were in human sciences faculties. 
Table (2): presents that, less than one-quarter of studied students (21.6\%) excessive physical affected as a result of prolonged internet usage. As regard psychosocial effects of prolonged internet usage, $31.3 \%$ of studied students excessive psychosocial affected as a result of prolonged internet usage. More than one-third of studied students (39.4\%) have excessive negative effects of internet usage on academic achievement. Also, $76.1 \%$ of studied students have a moderate level of internet addiction.

Table (3): shows that the majority of studied students (93.8\%) have a computer in their homes. Around one-quarter $(24.5 \%)$ of studied students play computer game one to two times per month, more than one-quarter $(29.9 \%)$ of them use the internet for 3hours and more per day.

Table (4): shows that the excessive internet addiction level is higher among the students aged 19 years old $(71.7 \%)$ and most of them are female $(64.2 \%)$. There is no statistically significant relation between internet addiction level in relation to age and gender of studied students. Regarding faculty type, the excessive internet addiction level is higher among the human sciences students $(61.7 \%)$. There was no statistically significant relation.

Table (5): illustrates that the excessive internet addiction level is statistically significantly among the students who have a computer at home $(\mathrm{P}=0.018)$. Also, the table shows that the excessive internet addiction level is statistically significantly among the student with daily playing computer games $(\mathrm{P}=0.003)$. The table also illustrates the excessive internet addiction level is statistically significantly among those with daily use of internet 3 hours and more per day $(\mathrm{P}=0.043)$.

Table (1): Personal characteristics of the studied university adolescent students and their parents

\begin{tabular}{|l|c|c|}
\hline \multirow{2}{*}{ Personal characteristics } & \multicolumn{2}{|c|}{ Studied students (n=515) } \\
\cline { 2 - 3 } & No. & \% \\
\hline \hline Gender & 204 & 39.6 \\
Male & 311 & 60.4 \\
Female & & \\
\hline Residence & 445 & 86.4 \\
Urban & 70 & 13.6 \\
Rural & & \\
Faculty & 339 & 65.8 \\
Human sciences & 157 & 30.5 \\
Mathematical sciences & 19 & 3.7 \\
Healthy sciences & & \\
\hline
\end{tabular}


Table (2): Total score of internet addictive behavior scale among the studied university adolescent students

\begin{tabular}{|l|c|c|c|c|c|c||}
\hline \multirow{2}{*}{} & \multicolumn{5}{|c|}{ Studied students (n=515) } \\
\cline { 2 - 7 } & \multicolumn{2}{|c|}{ Minimal } & \multicolumn{2}{|c|}{ Moderate } & \multicolumn{2}{c|}{ Excessive } \\
\cline { 2 - 7 } & No. & \% & No. & \% & No. & \% \\
\hline \hline Assessment of habitual internet use & 9 & 1.7 & 471 & 91.5 & 35 & 6.8 \\
\hline Purpose of internet use & 1 & 0.2 & 115 & 22.3 & 399 & 77.5 \\
\hline Physical effects of prolonged internet usage & 51 & 9.9 & 353 & 68.5 & 111 & 21.6 \\
\hline Psychosocial effects of prolonged internet usage & 27 & 5.2 & 327 & 63.5 & 161 & 31.3 \\
\hline Financial problems of prolonged internet usage & 88 & 17.1 & 263 & 51.1 & 164 & 31.8 \\
\hline $\begin{array}{l}\text { Dependence criteria, tolerance, and withdrawal } \\
\text { symptoms of internet }\end{array}$ & 63 & 12.2 & 306 & 59.4 & 146 & 28.4 \\
\hline $\begin{array}{l}\text { Negative effects of internet usage on academic } \\
\text { achievement }\end{array}$ & 63 & 12.2 & 249 & 48.3 & 203 & 39.4 \\
\hline Total score & 3 & 0.6 & 392 & 76.1 & 120 & 23.3 \\
\hline
\end{tabular}

Table (3): Internet use among the studied university adolescent students.

\begin{tabular}{|l|c|c|}
\hline \multirow{2}{*}{ Internet use } & \multicolumn{2}{c|}{ Studied students (n=515) } \\
\cline { 2 - 3 } & No. & \% \\
\hline \hline Have computer at home & & \\
Yes & 483 & 93.8 \\
No & 32 & 6.2 \\
\hline Frequency of playing computer games & & \\
Never & 105 & 20.4 \\
One to two times per month & 126 & 24.5 \\
Once per week & 81 & 15.7 \\
Several times per week & 95 & 18.4 \\
Daily & 108 & 21.0 \\
& & \\
\hline Duration of daily use of internet/ hours & & 29.9 \\
Not use & 154 & 12.8 \\
1- & 66 & 19.0 \\
2- & 98 & 29.9 \\
3- & 154 & 8.3 \\
$4+$ & 43 & \\
\hline
\end{tabular}

* Not mutually exclusive 
Table (4): Relation between internet addiction levels and personal characteristics of studied university adolescent students

\begin{tabular}{|c|c|c|c|c|c|}
\hline \multirow{3}{*}{ Personal characteristics } & \multicolumn{4}{|c|}{ Internet addiction levels } & \multirow{3}{*}{ Significance } \\
\hline & \multicolumn{2}{|c|}{$\begin{array}{c}\text { Minimal/moderate } \\
(\mathbf{n}=395)\end{array}$} & \multicolumn{2}{|c|}{$\begin{array}{c}\text { Excessive } \\
(n=120)\end{array}$} & \\
\hline & No. & $\%$ & No. & $\%$ & \\
\hline Gender & & & & & \multirow{3}{*}{$\begin{array}{c}X^{2}=0.934 \\
P=0.334\end{array}$} \\
\hline Male & 161 & 40.8 & 43 & 35.8 & \\
\hline Female & 234 & 59.2 & 77 & 64.2 & \\
\hline Residence & & & & & \multirow{3}{*}{$\begin{array}{c}\mathrm{X}^{2}=0.009 \\
\mathrm{P}=0.925\end{array}$} \\
\hline Urban & 341 & 86.3 & 104 & 86.7 & \\
\hline Rural & 54 & 13.7 & 16 & 13.3 & \\
\hline Type of faculty & & & & & \multirow{4}{*}{$\begin{array}{l}\mathrm{X}^{2}=2.479 \\
{ }_{\mathrm{MC}}=0.285\end{array}$} \\
\hline Human sciences & 265 & 67.1 & 74 & 61.7 & \\
\hline Mathematical sciences & 114 & 28.9 & 43 & 35.8 & \\
\hline Healthy sciences & 16 & 4.1 & 3 & 2.5 & \\
\hline
\end{tabular}

X2: Chi-Square test

MCP: Monte Carlo corrected P-value

Table (5): Relation between internet addiction levels and internet use of studied university adolescent students

\begin{tabular}{|c|c|c|c|c|c|}
\hline \multirow{3}{*}{ Internet use } & \multicolumn{4}{|c|}{ Internet addiction levels } & \multirow{3}{*}{ Significance } \\
\hline & \multicolumn{2}{|c|}{$\begin{array}{c}\text { Minimal/moderate } \\
\qquad(\mathrm{n}=395)\end{array}$} & \multicolumn{2}{|c|}{$\begin{array}{c}\text { Excessive } \\
(n=120)\end{array}$} & \\
\hline & No. & $\%$ & No. & $\%$ & \\
\hline \multicolumn{6}{|l|}{ Have computer at home } \\
\hline Yes & 365 & 92.4 & 118 & 98.3 & $X^{2}=5.55$ \\
\hline No & 30 & 7.6 & 2 & 1.7 & $\mathrm{P}=0.018^{*}$ \\
\hline \multicolumn{6}{|l|}{$\begin{array}{l}\text { Frequency of playing computer } \\
\text { games }\end{array}$} \\
\hline Not use & 84 & 21.3 & 21 & 17.5 & \multirow{5}{*}{$\begin{array}{l}X^{2}=15.726 \\
P=0.003^{*}\end{array}$} \\
\hline One to two time per month & 105 & 26.6 & 21 & 17.5 & \\
\hline Once per week & 62 & 15.7 & 19 & 15.8 & \\
\hline Several times per week & 76 & 19.2 & 19 & 15.8 & \\
\hline Daily & 68 & 17.2 & 40 & 33.3 & \\
\hline \multicolumn{6}{|l|}{ Duration of daily use of internet } \\
\hline Not use & 127 & 32.2 & 27 & 22.5 & \\
\hline $1-$ & 56 & 14.2 & 10 & 8.3 & $X^{2}=9.06$ \\
\hline $2-$ & 70 & 17.7 & 28 & 23.3 & $\mathrm{P}=0.043^{*}$ \\
\hline $3-$ & 113 & 28.6 & 41 & 34.2 & \\
\hline $4+$ & 29 & 7.3 & 14 & 11.7 & \\
\hline
\end{tabular}

$X^{2}$ : Chi-Square test $\quad{ }^{M C} P$ : Monte Carlo corrected P-value $\quad *$ significant at $P \leq 0.05$ 


\section{DISCUSSION:}

Global rates of internet use have increased considerably over the past few decades (Kaess et al., 2014). Internet use becomes pathological when it interferes with one or more major areas of life functioning such as significant relationships, occupation, school, mental health, or physical health (Al-Hantoushi \& Al-Abdullateef, 2014). Internet addiction is observed in all age groups, it is most pronounced among adolescents (Seybert, 2012). University students are much more likely than the general population to use the internet (Li et al., 2015).

The present study was carried out to assess internet use and addiction by university adolescent students in order to highlight the consequences of the problem and draw attention to necessary rapid solutions. In the present study, internet addiction level was moderate and excessive among university students. The finding might be attributed to confounding factors such as the majority of studied students were from the urban area which had high internet access. Life in an urban area was characterized by welfare and no workload on adolescents, thus they have more leisure time spent in using the internet. This interpretation is supported by Pawlowska et al. (2015) who illustrated that the adolescents living in urban areas showed a significantly greater intensity of internet addiction symptoms, compared to those living in rural areas.

Similar to the foregoing current study results, Alhajjar (2014) investigate the prevalence of internet addiction among the nursing students at the Islamic University of Gaza and indicated that more than one-quarter of students scored high level of internet addiction. ) in Pakistan stated that more than one-third of university students are having a problematic internet addiction. This indicates the importance of preventing internet addiction among adolescents by building a healthy living environment around them, controlling the computer and internet use, promoting book reading and providing treatment to those with a psychological problem as emphasized by Sasmaz et al. (2013).

The current results revealed that the excessive internet addiction level was high among female students. The interpretation might be that girls' tendency to use the internet because they need to make new friends online, they cannot meet those people in person because of the cultural restriction on communicating with the people they would like to. Also, female spend most of the time in the home using a computer in a private room, on the other hand, male spend most of the time out of the home. Women seek out close friendships and prefer anonymous communication in which they can hide their appearance(s). Virtual communities give women a sense of belonging and the ability to share their feelings and emotions in private and convenient ways. This was evident to choose female individuals as the target group in studies focusing on curbing internet addiction at the university.

In line with the foregoing, several studies reported the same direct association between internet addiction and female gender (Jones et al., 2009; Heo et al., 2014). However, a study carried out in Turkey demonstrated that male students had higher internet addiction 
than female ones (Evren et al., 2014). These differences in findings might be the result of cultural differences in use of the internet.

The excessive internet addiction level was higher among human sciences students in the present study. This might be explained by that the theoretical students don't have excessive homework in their faculties which cause them login for a prolonged time and so they become excessive users of the internet. Also, the academic overload and the high pressure of study demands of mathematical and medical students, this may be a barrier towards having enough free time to overuse of the internet reach to a degree of addiction. This is congruent with Desouky\& Ibrahem (2015) who did a study to assess the prevalence of internet addiction and its relation to psychological morbidity among Egyptian university students and demonstrated that the majority of internet addicts were from the human sciences college. Meanwhile, Sepehrian \& Lotf (2011) stated that the excessive internet addiction level was higher among mathematical sciences students than that of human sciences students.

According to the results of the current study, the excessive internet addiction level was statistically significantly higher among the students who had a computer at home. This might be interpreted by that home access provides anytime, unlimited access and over privacy. This finding is confirmed by Gencer \&Koc (2012) who studied internet abuse among teenagers and its relations to internet usage patterns and demographics, noted that the level of internet abuse was the highest among those students who used the internet mostly at home. This results point out to the importance of the supervisory role the parent at home.

The excessive internet addiction level was statistically significantly among student with daily playing computer games in the current study. The interpretation might be that computer games consume a great and fun time. On the same line, Blinka et al. (2015), in Europe, found that playing games is a risk factor specifically associated with highly excessive internet use.

According to the present study findings, the excessive internet addiction level was statistically significantly higher among students with the daily use of internet 3 hours and more per day. This is quite important since the inability of adolescents to limit their time online, especially when they engage in chat and community websites, and the accessibility of 24 hours internet service at homes. Our result is in agreement with a study in Spain, which suggested a positive association between the total amount of time spent on the internet and internet addiction in university students (Gonzalez\& Orgaz, 2014).

\section{CONCLUSION:}

Based on the findings of the current study, it can be concluded that severe/ extremely severe internet addiction levels were higher among female students and human sciences students. Finally, the total score of internet addiction was moderate and excessive among university students. 


\section{RECOMMENDATIONS:}

Based on the findings of the present study, the following recommendations are suggested:

1. Continuous educational program for adolescents to teach them about the proper internet usage to avoid negative impacts. These programs should be led by health professionals, especially nurses and replace the excessive use of the internet with healthy activities like exercising, meditation and joining some team sports.

2. An educational program for all teaching staff in university especially in human sciences faculties about negative consequences of internet addiction in order to deliver the message to students.

3. An educational session is recommended to parents about their supervisory role at home is crucial and the importance of encouragement for their adolescents to participate in other creative activities beyond computer use.

\section{REFERENCES:}

Akin A., Iskender M. (2011). Internet addiction and depression, anxiety and stress. International Online Journal of Educational Sciences, 3(1), 138-148.

Alhajjar B. (2014). Internet addiction and psychological morbidity among nursing students in Gaza-Palestine. American Journal of Applied Psychology, 3(4): 99-103.

Al-hantoushi M., Al-Abdullateef S. (2013). Internet addiction among secondary school students in Riyadh city, its prevalence, correlates and relation to depression: A questionnaire survey. International Journal of Medical Science and Public Health, 3(1): $10-15$.

Azher M., Khan R., Salim M., Bilal M., Hussain A., Haseeb M. (2014). The relationship between internet addiction and anxiety among students of the university of Sargodha. International Journal of Humanities and Social Science, 4 (1):288-293.

Blinka L., Skarupova K., Sevcikova A., Wolfling K., Muller D. (2015). "Excessive internet use in European adolescents: What determines differences in severity?" International Journal of Public Health, 60 (2): 249-257.

Chou C., Condron L., Belland J. (2005). A review of the research on internet addiction. Educational Psychology Review, 17(4):363-388.

Christopherson C. (2008). Addiction and volition in problematic internet use among college students. UN published master thesis, faculty of Arts, University of Notre Dame. Indiana. 1-18.

Desouky D., Ibrahem R. (2015). Internet addiction and psychological morbidity among Menoufia University students, Egypt. American Journal of Public Health Research, 3(5): 192-198. 
Dreier M., Tzavela E., Wölfling K., Mavromati F., Duven E., Karakitsou C., Macarie G., Veldhuis L., Wójcik S., Halapi E., Sigursteinsdottir H., Oliaga A., Tsitsika A. (2013). The development of adaptive and maladaptive patterns of Internet use among European adolescents at risk for Internet Addictive Behaviors: A Grounded Theory inquiry. National and Kapodistrian University of Athens (N.K.U.A.), Athens. available at: www.eunetadb.eu. Retrieved at: January, 2016.

Elkotb H. (2013). Impact of internet addiction on psychological problems among Menoufia University students. Unpublished Master thesis, Faculty of Nursing, Menoufia University. Egypt. 97- 99.

Evren C., Dalbudak E., Evren B., Demirci A. (2014). High risk of internet addiction and its relationship with lifetime substance use, psychological and behavioral problems among 10th-grade adolescents. Psychiatria Danubina, 26 (4): 330-339.

Gencer, S., Koc M. (2012). Internet abuse among teenagers and its relations to internet usage patterns and demographics. Educational Technology \& Society, 15 (2), 25-36.

Gonzalez E., Orgaz B. (2014). Problematic online experiences among Spanish college students: Associations with internet use characteristics and clinical symptoms. Computer Human Behavior, 31: 151-158.

Heo J., Oh J., Subramanian S., Kim Y, Kawachi I. (2014). Addictive internet use among Korean adolescents: A National Survey. PlOs One, 9(2): 1-8.

Jones S., Johnson-Yale C., Millermaier S., Perez S. (2009). U.S. college students' internet use: Race, gender, and digital divides. Journal of Computer-Mediated Communication, 14(2): 244-264.

Kaess M., Durkee T., Brunner R., Carli V., Parzer P., Wasserman C., Sarchiapone M., Hoven C., Apter A., Balazs J., Balint M., Bobes J., Cohen R., Cosman D., Cotter P., Fischer G., Floderus B., Iosue M., Haring C., Kahn J., Musa G., Postuvan N., Resch F., Saiz P., Sisask M., Snir A., Varnik A., Iberna J., Wasserman D. (2014). Pathological internet use among European adolescents: psychopathology and self-destructive behaviors. European Child \& Adolescent Psychiatry, 23(11):1093-1102.

Lam L., Peng Z., Mai J., Jing J. (2009). Factors associated with internet addiction among adolescents. Cyber psychology\& Behavior, 12(5): 551- 5.

Li W., O'Brien J., Snyder S., Howard M. (2015). Characteristics of internet addiction/ pathological internet use in U.S. university students: A qualitative method investigation. PLoS ONE, 10 (2):1-19.

Milani L., Osualdella D., Di B. (2009). Quality of interpersonal relationships and problematic internet use in adolescence. Cyber psychology\& Behavior, 12(6): 681-4. 
Morsy M., Shalaby N. (2012). The use of technology by university adolescent students and its relation to attention, sleep, and academic Achievement. Journal of American Science, 8(1): 264-270.

Naffise M., Mohammad A., Ahmad P., Omid R., Ayatollahi A., Reza B., Fatemeh A.(2013). The prevalence of internet addiction among the students of Rafsanjan University of medical sciences. ASEAN Journal of Psychiatry, 14 (2):1-8.

Ni X., Yan H., Chen S., Liu Z. (2009). Factors influencing internet addiction in a sample of freshmen university students in China. Cyber psychology\& Behavior, 12(3): 327-30.

Pawlowska B., Zygo M., Potembska E., Kapka-Skrzypczak L., Dreher P., Kędzierski Z.(2015). Prevalence of internet addiction and risk of developing addiction as exemplified by a group of Polish adolescents from urban and rural areas. Annals of Agricultural and Environmental Medicine, 22(1): 129-136.

Sally L. (2006). Prediction of internet addiction for undergraduates in Hong Kong. An Honours Degree Project, the School of business, Hong Kong Baptist University, Hong Kong. 10- 12.

Sasmaz T., Oner S., Kurt A., Yapici G., Yazisi A., Bugdayci R, Sis M.(2014). Prevalence and risk factors of internet addiction in high school students. European Journal of Public Health, 24(1):15-20.

Sepehrian F, Lotf J. (2011). Study of the relationship between internet addiction with anxiety and personality types A and B. Australian Journal of Basic and Applied Sciences, 5(11): 928-934.

Seybert H. (2012). Internet use in households and by individuals in 2012. Industry, trade, and services, 50:1-8.

The World Bank group (2014):Available at data.worldbank.org/indicator/IT.NET.USER.P2 Retrieved at February, 2015.

Wadie N. (2006). Psychosocial variables associated with internet addictive behaviors, Unpublished Master Thesis, Faculty of Nursing, Cairo University. Egypt. 89- 99.

World Health Organization (WHO) (2014). Available at: http://www.who.int/en/ Retrieved at February, 2015. 


\section{استخدام و إدمان الانترنت لاى طلاب الجامعة المراهقين}

أ.د أمل أحمد خليل / د ـ أمل صبحي محمود/ د. عبير السيد برمده/ م.م. هدى جابر حمزه

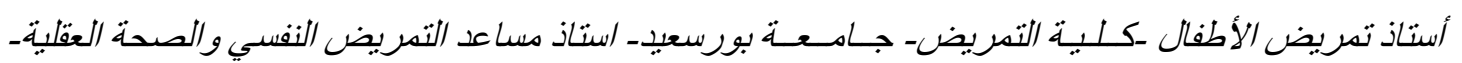

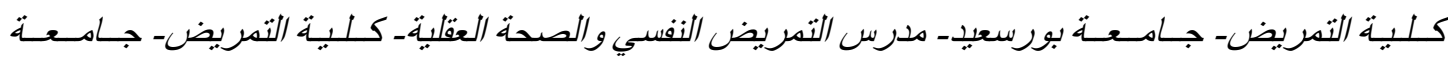

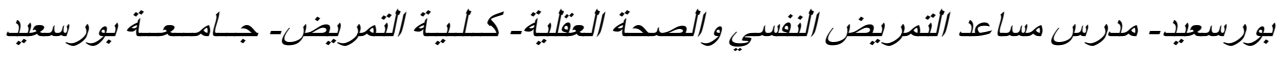

\section{النـلاصـة}

يعتبر الثباب وخاصة طلاب الجامعات هم الأكثر استخداما للإنترنت ولكن أستخدامه الزائد يؤدي الى درجة

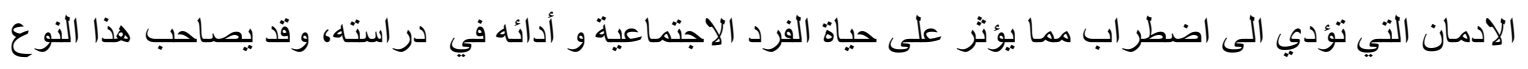

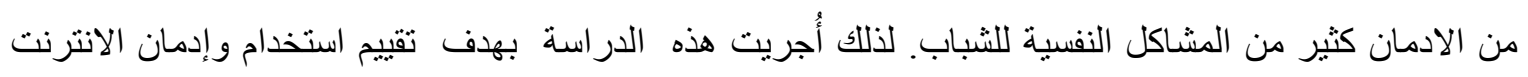

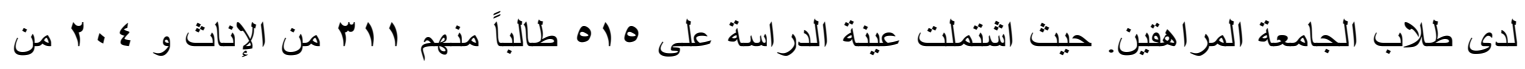
الذكور قد تم اختيار هم من جميع كليات جامعة بورسعيد حسب عددهم وتم جمع البيانات الخاصة بالدر اسة بإستخدام

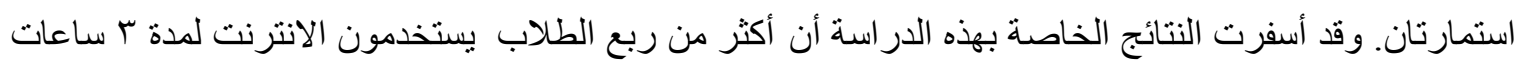
و أكثر يو ميا.و أن مستوى إدمان الانترنت أعلى بين الطلاب الإناث و أيضا بين الطلاب في كليات العلوم الإنسانية.

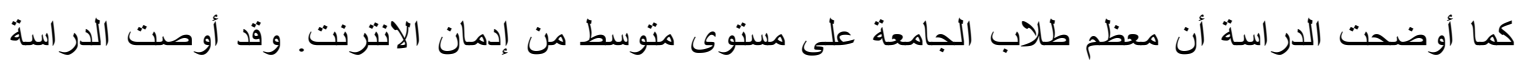

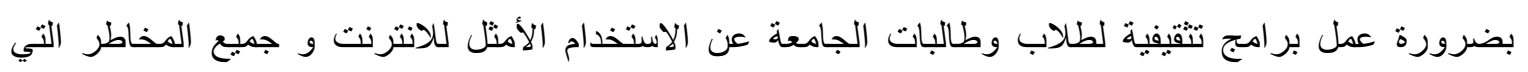
يتعرضون لها جر اء الاستخدام الزائد للانترنت ومحاولة استبدال الاستخدام الزائد للانترنت بالاشتر الك في الأنشطة المختلفة مثل الألعاب الرياضية. كما يجب عمل فصول تثقيفية وتعليمية للأباء عن الانترنت ومخاطر أستخدامه الأه الزائد و أهمية ملاحظة أبنائهم أثناء استخدام الانترنت. الكلمات المرشدة : الطلاب المر/هقين، ادمان الانترنت،و /ستخدم الانترنت 